\title{
Renal Excretion of Urobilinogen in the Dog
}

\author{
Mortimer Levy, Roger Lester, and Norman G. Levinsky \\ From the Fifth and Sixth (Boston University) Medical Services, Boston City \\ Hospital, and the Department of Medicine, Boston University School of \\ Medicine, Boston University Medical Center, Boston, Massachusetts 02118
}

A в S T R A C T The renal excretion of urobilinogen was studied in dogs by standard clearance techniques. The use of radiochemically pure tritiated mesobilirubinogen as a representative urobilinogen afforded much greater analytical precision than can be obtained with the usual colorimetric and fluorimetric techniques which are only semiquantitative. With constant plasma levels of urobilinogen, raising urinary $\mathrm{pH}$ from 5 to 8 increased urobilinogen excretion from about $30 \%$ to up to $200 \%$ of the filtered load. When urinary $\mathrm{pH}$ was kept constant, changes in blood $\mathrm{pH}$ had no effect on urobilinogen excretion. Increases in urinary flow had no effect on urobilinogen excretion when the urine was alkaline but increased excretion markedly during aciduria. Probenecid did not influence urobilinogen excretion by the kidney. It is concluded that urobilinogen is excreted by a three-component system of glomerular filtration, active secretion, and $\mathrm{pH}$-dependent nonionic diffusion in the distal nephron. Urobilinogen is a weak acid, and this mode of excretion is similar to that of other weak, organic acids, such as salicylates. These results indicate that urinary $\mathrm{pH}$ and flow must be considered in the clinical interpretation of measurements of urinary urobilinogen.

This work was presented in part before the American Federation for Clinical Research, National Meeting, Atlantic City, N. J., April, 1967.

Dr. Levinsky is an Established Investigator of the American Heart Association.

Address reprint requests to Dr. Norman G. Levinsky, Boston University Medical Center, 15 Stoughton Street, Boston, Mass. 02118.

Received for publication 25 March 1968 and in revised form 27 May 1968.

\section{INTRODUCTION}

Considering how frequently urobilinogen is estimated clinically, surprisingly little is known about the mechanism of urobilinogen excretion. Three studies of urobilinogen excretion in man have come to three different conclusions : that excretion is by glomerular filtration alone (1), that both filtration and tubular secretion occur (2), and that excretion is a complex process involving filtration, secretion, and reabsorption by $\mathrm{pH}$-dependent nonionic diffusion (3). The only previous study in the dog suggested that glomerular filtration alone is involved (2). All these results, however, depend on spectrophotometric or fluorescent analytical techniques which probably are not completely reliable (3). In order to obtain greater analytical accuracy, we have, therefore, restudied this problem in dogs, taking advantage of the availability of techniques for the preparation of radiolabeled urobilinogen (4). Our data extend the observations of Bourke, Milne, and Stokes (3) and support their conclusions as to the mechanism of urobilinogen excretion.

\section{METHODS}

Experiments were performed on 28 female mongrel dogs, anaesthetized with sodium pentobarbital. Food and water were removed 15-18 $\mathrm{hr}$ before an experiment.

Preparation and administration of tritiated mesobilirubinogen (urobilinogen ${ }^{8} \mathrm{H}$ ). Mesobilirubinogen $-{ }^{8} \mathrm{H}$, a representative urobilinogen, was prepared by catalytic reduction of bilirubin in the presence of tritiated water, according to the method of Lester and Klein (4). This compound has been shown to be radiochemically pure (4), and it has been established that it behaves in vivo identically to $\mathrm{C}^{14}$-labeled mesobilirubinogen (5).

Urobilinogen ${ }^{-3} \mathrm{H}$ prepared as a lyophilized powder was stored in sealed vials at $-20^{\circ} \mathrm{C}$. Just before an experi- 
ment, vials were opened and the contents dissolved in $0.7-1.0 \mathrm{ml}$ of methanol or ethanol. This was further diluted 2.5 times in distilled water and the entire volume added to $10-20 \mathrm{ml}$ of autologous fresh heparinized plasma. An aliquot of this solution was set aside in order to determine the total amount of urobilinogen administered to the dog (approximately $0.5-1.0 \mathrm{mg}$ ). The remainder was then administered to the dog by constant intravenous infusion at a rate of $0.04 \mathrm{ml} / \mathrm{min}$ (approximately $2-3 \mu \mathrm{g} / \mathrm{min}$ ) after an initial prime of $1.5-2.0 \mathrm{ml}$ had been given. At least $30 \mathrm{~min}$ was allowed for equilibration before the start of an experiment. During the experiment the urobilinogen was kept covered to avoid exposure to light; marked color change, indicating significant urobilin formation, was never noted.

Clearance experiments. The renal excretion of urobilinogen $-{ }^{3} \mathrm{H}$ was studied by conventional clearance techniques. The clearance of exogenous creatinine was used to measure glomerular filtration rate (GFR). Urine was collected from a retention catheter in the bladder, and blood samples were taken from an indwelling arterial needle. All infusions were administered intravenously by constant infusion pumps.

To induce urinary acidification; dogs were given 10.0 $\mathrm{g}$ of ammonium chloride daily for 2 days before an experiment, and $0.015 \mathrm{~N} \mathrm{HCl}$ in $0.9 \%$ saline was infused intravenously during appropriate periods of the experiment. Alkaline urines were produced by changing this infusion to $0.15 \mathrm{~m}$ or $0.30 \mathrm{M} \mathrm{NaHCO}_{3}$. When urine $\mathrm{pH}$ was to be determined, small aliquots of urine were collected under oil at the mid-point of each clearance period.

Analytical techniques. Samples of plasma and urine containing urobilinogen $-{ }^{8} \mathrm{H}$ were counted in a Packard Tri-carb liquid scintillation counter as previously described (4). Internal standard was added to each vial to correct for quenching. Counting efficiency was generally $8-15 \%$. Thin-layer chromatography of urobilinogen $-{ }^{8} \mathrm{H}$ was carried out as previously described (4).

Blood $\mathrm{pH}$ was measured with the capillary electrode of a Radiometer $\mathrm{pH}$ meter (Radiometer Co., Copenhagen). Urinary $\mathrm{pH}$ was determined immediately after collection of a sample, using a Corning $\mathrm{pH}$ meter. Readings were made at room temperature and corrected to $37^{\circ} \mathrm{C}$. Serum proteins were measured by refractometry. Creatinine was determined on an Auto-Analyzer.

Protein binding of urobilinogen was measured several times during each experiment. All analyses were performed in duplicate. $3.5 \mathrm{ml}$ of plasma was centrifuged under oil for $16 \mathrm{hr}$ at approximately $125,000 \mathrm{~g}_{\max }$, using a No. 40 rotor, in a Beckman Model L ultracentrifuge. At the end of this time, the serum proteins had been concentrated into a reddish-orange pellet at the bottom of the tube, and $0.5 \mathrm{ml}$ of clear supernatant was aspirated for counting. This supernatant was essentially proteinfree when checked by refractometry or with biuret reagent. It was counted in the same way as plasma and urine samples (4).

Calculations. Urobilinogen excretion was evaluated from the clearance of free, or unbound, urobilinogen. The clearance of free urobilinogen was calculated as equal to urobilinogen excretion/plasma free urobilinogen. Urobilinogen excretion, $\mathrm{dpm} / \mathrm{min}=$ urinary urobilinogen, $\mathrm{dpm} / \mathrm{ml}, \times$ urine flow, $\mathrm{ml} / \mathrm{min}$.. Plasma free urobilinogen $=$ total plasma urobilinogen, $\mathrm{dpm} / \mathrm{ml}, \times$ fraction of unbound plasma urobilinogen, as estimated by ultracentrifugation several times in each experiment. Binding was determined directly on about one-half of the plasma samples in each experiment and was interpolated for the other values.

\section{RESULTS}

Protein binding. During the infusion of urobilinogen into dogs, the steady-state plasma concentrations of the infused material were of the order of $2-3 \mu \mathrm{g} / 100 \mathrm{ml}$ (range, $0.6-5 \mu \mathrm{g} / 100 \mathrm{ml}$ ). There was great variation among dogs in the fraction of urobilinogen bound to plasma proteins. The mean of 42 observations was $46.1 \pm 10.1 \%$ (sD) bound, with a range from 28 to $67 \%$. However, values for a given dog remained quite constant throughout the course of an experiment. Protein binding seemed to be unaffected by the use of heparinized plasma as opposed to serum and by blood $\mathrm{pH}$ changes in the range 7.1-7.55. In a few dogs, dilution of plasma proteins decreased binding slightly. When large amounts of carrier urobilinogen were infused, plasma concentrations of $50-2500 \mu \mathrm{g} / 100 \mathrm{ml}$ were obtained. Under these conditions, protein binding was decreased slightly $(38.6 \pm 9.3 \%, \mathrm{n}=14)$ as compared to the experiments in which only tracer amounts were infused, but the difference was not statistically significant. Because Bourke et al. (3) reported little scatter for the protein binding of urobilinogen in human sera $(77-85 \%)$, we studied the binding of urobilinogen ${ }^{3} \mathrm{H}$ in human serum by ultracentrifugation, as described in Methods, and by ultrafiltration. By ultracentrifugation, values of $70.7-72.9 \% \quad(n=9)$ were obtained in human sera, and by ultrafiltration, values were 68.8 $76.0 \%(n=6)$. These results provide evidence that the ultracentrifugation method used in our present dog studies is a valid technique for determining protein binding. They also suggest that the large scatter observed in dogs in contrast to the uniformity of protein binding in man is probably due to species difference.

Validity of urobilinogen ${ }^{3} \mathrm{H}$ clearance measurements. The validity of clearances with mesobilirubinogen $-{ }^{3} \mathrm{H}$ depends on the assumptions that this substance is excreted unaltered and with the 
isotopic label intact. That this was indeed so in our experiments was determined in two different ways. First, it was demonstrated by thin-layer chromatography that the $R_{f}$ value for urobilinogen- ${ }^{3} \mathrm{H}$ extracted from dog urine was identical to that of the infusate. Moreover, all the radioactivity on the chromatograph corresponded to the urobilinogen band. Secondly, large amounts of carrier urobilinogen ${ }^{3} \mathrm{H}$ were infused into two dogs and serial urine collections made. The specific activity of the urinary urobilinogen was 95 and $105 \%$ that of the infusate. These data indicate that urobilinogen ${ }^{-3} \mathrm{H}$ is excreted in the urine without significant alteration, and that urinary radioactivity is an accurate index of urobilinogen excretion.

Influence of urinary $p H$ on urobilinogen ${ }^{3} \mathrm{H}$ excretion. In clearance experiments in which plasma levels of urobilinogen ${ }^{3} \mathrm{H}$ and urine flow were held relatively constant, progressive increases in urinary $\mathrm{pH}$ produced marked changes in urobilinogen excretion. Data from eight dogs are plotted in Fig. 1, and a detailed experimental protocol is given in Table $\mathrm{I}$. As urinary $\mathrm{pH}$ was progressively elevated, urobilinogen excretion increased from as little as $30 \%$ of the filtered load in

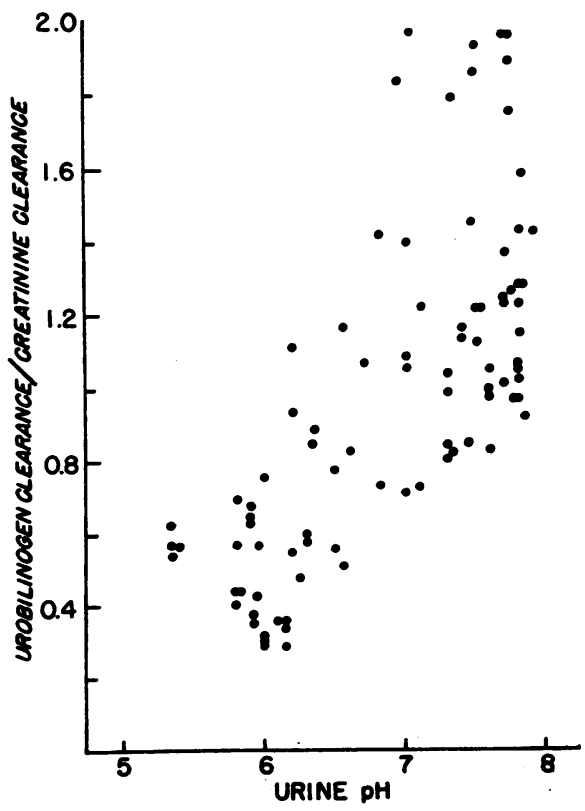

FIGURE 1 Effect of urinary $\mathrm{pH}$ on urobilinogen- ${ }^{8} \mathrm{H}$ excretion. Data are from eight dogs; each point represents one clearance period. Urine flow (V)/glomerular filtration rate (GFR) was relatively constant in these experiments.
TABLE I

Effect of Urine $p H$ on Urobilinogen Excretion

\begin{tabular}{|c|c|c|c|c|c|c|}
\hline Time & $\begin{array}{l}\text { Urine } \\
\text { pH }\end{array}$ & GFR & V & V/ & $\mathrm{Cu}_{\mathrm{u}}$ & $\begin{array}{c}C_{w} / \\
\text { GFR } \\
\times 100\end{array}$ \\
\hline $\min$ & & $\begin{array}{l}m l / \\
m i n\end{array}$ & $\begin{array}{l}m l / \\
m i n\end{array}$ & $\%$ & $\begin{array}{c}m l / \\
m i n\end{array}$ & \\
\hline-175 & \multirow{2}{*}{\multicolumn{6}{|c|}{$\begin{array}{l}1 \mathrm{~g} \text { of creatinine prime; infusion started at } 10.5 \mathrm{mg} / \mathrm{min} \\
\text { in water } \\
0.015 \mathrm{~N} \mathrm{HCl} \text { in } 0.9 \% \text { saline infused at } 4.4 \mathrm{ml} / \mathrm{min} \\
\text { Urobilinogen-s } \mathrm{H}, 1.5 \mathrm{ml} \text { prime; infusion started at } 0.034 \\
\mathrm{ml} / \mathrm{min}\end{array}$}} \\
\hline $\begin{array}{r}-151 \\
-35\end{array}$ & & & & & & \\
\hline $0-6$ & 5.9 & 41 & 2.3 & 5.7 & 28 & 68 \\
\hline $6-12$ & 5.9 & 37 & 2.3 & 6.4 & 24 & 64 \\
\hline $12-18$ & 5.9 & 40 & 2.3 & 5.8 & 27 & 66 \\
\hline $18-25$ & 5.8 & 42 & 2.7 & 0.4 & 30 & 71 \\
\hline 34 & \multicolumn{6}{|c|}{$\begin{array}{l}\text { Start } 0.15 \mathrm{M} \mathrm{NaHCO} \text { at } 8.5 \mathrm{ml} / \mathrm{min} \text {, discontinue } \mathrm{HCl} \\
\text { infusion }\end{array}$} \\
\hline $40-52$ & 6.0 & 41 & 2.1 & 5.1 & 31 & 76 \\
\hline $52-58$ & 6.2 & 42 & 2.2 & 5.3 & 47 & 112 \\
\hline $58-66$ & 6.35 & 42 & 2.1 & 4.9 & 47 & 112 \\
\hline 70 & \multicolumn{6}{|c|}{ Increase $\mathrm{NaHCO}_{3}$ infusion to $16.4 \mathrm{ml} / \mathrm{min}$} \\
\hline $70-81$ & 6.55 & 46 & 2.5 & 4.7 & 41 & 90 \\
\hline 81-89 & 6.55 & 36 & 1.7 & 4.3 & 43 & 119 \\
\hline 89-99 & 6.8 & 47 & 2.0 & 4.3 & 59 & 125 \\
\hline $99-111$ & 6.8 & 43 & 1.9 & 5.0 & 62 & 144 \\
\hline 111-117 & 6.9 & 46 & 2.3 & 5.6 & 86 & 186 \\
\hline 119 & \multicolumn{6}{|c|}{ Increase $\mathrm{NaHCO}$ infusion to $32 \mathrm{ml} / \mathrm{min}$} \\
\hline $119-125$ & 7.3 & 57 & 3.2 & 5.4 & 119 & 210 \\
\hline $125-132$ & 7.3 & 44 & 3.2 & 7.3 & 81 & 182 \\
\hline $132-138$ & 7.45 & 36 & 4.1 & 11.6 & 76 & 214 \\
\hline $138-945$ & 7.45 & 39 & 5.0 & 12.0 & 75 & 193 \\
\hline
\end{tabular}

GFR, glomerular filtration rate; $V$, urine flow; $C_{u}$, clearance of unbound urobilinogen-2 $\mathrm{H}$.

the acid urines to as much as twice the filtered load in urines of maximal alkalinity. Thus, while net reabsorption of urobilinogen was occurring during aciduria, net secretion was usually observed when the urine was alkaline. Since the free urobilinogen clearance-to-creatinine clearance ratio $\left(\mathrm{C}_{\mathrm{u}} / \mathrm{C}_{\mathrm{cr}}\right)$ reached 2 in some cases, the rate of secretion can at least equal the rate at which urobilinogen is being filtered.

In four experiments, an alkaline urine was achieved by inducing respiratory alkalosis. The dogs were hyperventilated by means of a mechanical respirator for an hour or more until the urine became alkaline. At a urine $\mathrm{pH}$ of $6.5, \mathrm{C}_{\mathrm{u}} / \mathrm{C}_{\mathrm{cr}}$ was 0.77 during hyperventilation; at $\mathrm{pH} 7.1,1.31$; at $\mathrm{pH} 7.3,1.55$; at $\mathrm{pH} 7.4,1.49$. (Each value is the mean of two to five clearance collections in one experiment.) $\mathrm{C}_{\mathrm{u}} / \mathrm{C}_{\mathrm{er}}$ at any urinary $\mathrm{pH}$ was approximately equivalent when urine alkalinity was produced by this technique or by bicarbonate infusion, as may be seen by comparing these values with Fig. 1. These experiments indicate that the 
TABLE II

Failure of Changes in Blood $\mathrm{pH}$ to Alter Urobilinogen Excretion

\begin{tabular}{|c|c|c|c|c|}
\hline Time & $\begin{array}{c}\text { Urine } \\
\text { pH }\end{array}$ & $\begin{array}{c}\text { Blood } \\
\text { pH }\end{array}$ & GFR & $\begin{array}{c}\mathrm{Cu}_{\mathrm{u}} / \mathrm{GFR} \\
\times 100\end{array}$ \\
\hline $\min$ & \multicolumn{4}{|c|}{$m l / m i n$} \\
\hline $\begin{array}{l}-93 \\
-34\end{array}$ & \multicolumn{4}{|c|}{$\begin{array}{l}\text { Urobilinogen prime and infusion at } 0.4 \\
\mathrm{ml} / \mathrm{min}\end{array}$} \\
\hline $0-20$ & 6.2 & 7.26 & 33 & 50 \\
\hline $20-38$ & 6.2 & 7.27 & 32 & 60 \\
\hline $38-54$ & 6.2 & 7.27 & 29 & 40 \\
\hline \multicolumn{5}{|c|}{ Start mechanical respirator } \\
\hline $57-67$ & 6.2 & 7.50 & 33 & 40 \\
\hline $67-77$ & 6.2 & 7.54 & 38 & 50 \\
\hline
\end{tabular}

Abbreviations as in Table I.

volume loading which occurred during the induction of alkalosis with bicarbonate infusions was not a factor in the increased urobilinogen excretion which occurred.

The production of alkaline urines by infusion of $\mathrm{NaHCO}_{3}$ and by prolonged hyperventilation of necessity led to mild systemic alkalosis. To determine whether net secretion of urobilinogen was in fact being caused by changes in plasma, rather than urinary $\mathrm{pH}$, clearance periods were collected in two dogs before and within the first $20-30 \mathrm{~min}$ after hyperventilation by means of a mechanical respirator was begun. This maneuver produced marked systemic alkalosis without initially influencing urinary $\mathrm{pH}$. The results of one such experiment are shown in Table II. Systemic alkalosis per se had no effect on the excretion of urobilinogen- ${ }^{3} \mathrm{H}$.

Effect of urine flow on urobilinogen ${ }^{3} \mathrm{H}$ excretion. The effect of varying urine flow when urinary $\mathrm{pH}$ is held constant was studied in 6 dogs under conditions of aciduria, and in three dogs passing alkaline urines (produced by either prolonged hyperventilation or prefeeding $\mathrm{NaHCO}_{3}$ ). Increasing urinary flow rates were produced by infusing increasing amounts of $3 \%$ urea in saline as an osmotic diuretic. When the urine was acid initially, urinary $\mathrm{pH}$ fell $0.5 \mathrm{U}$ below control values in one experiment as the osmotic diuresis progressed, increased up to $0.8 \mathrm{U}$ in three experiments, and remained virtually constant in two experiments. When the dogs initially were passing alkaline urines, the $\mathrm{pH}$ tended to fall slightly (up to $0.5 \mathrm{U}$ ) as the duiresis increased. The results obtained in all experiments of each type were similar. One representative experiment of each type is shown in Fig. 2. Under conditions of aciduria, $\mathrm{C}_{\mathrm{u}} / \mathrm{C}_{\mathrm{cr}}$ ratio increases markedly as urine flow increases up to $3-5 \%$ of GFR, but tends to level off at flows beyond this rate. When the urine is alkaline variation in flow rate has no appreciable effect on the $\mathrm{C}_{\mathrm{u}} / \mathrm{C}_{\mathrm{cr}}$ ratio.

Effect of probenecid on urobilinogen $-{ }^{3} \mathrm{H}$ excretion. We attempted to demonstrate a transport maximum $(\mathrm{Tm})$ for urobilinogen by infusing large amounts of urobilinogen- ${ }^{3} \mathrm{H}$ under conditions of alkaline diuresis, but we failed due to technical difficulties in preparing, handling, and infusing large amounts of carrier urobilinogen. It seemed of interest, therefore, to test the effect of probenecid, ${ }^{1}$ a potent inhibitor of the organic acid

${ }^{1}$ Kindly supplied by Merck, Sharpe \& Dohme, West Point, $\mathrm{Pa}$.

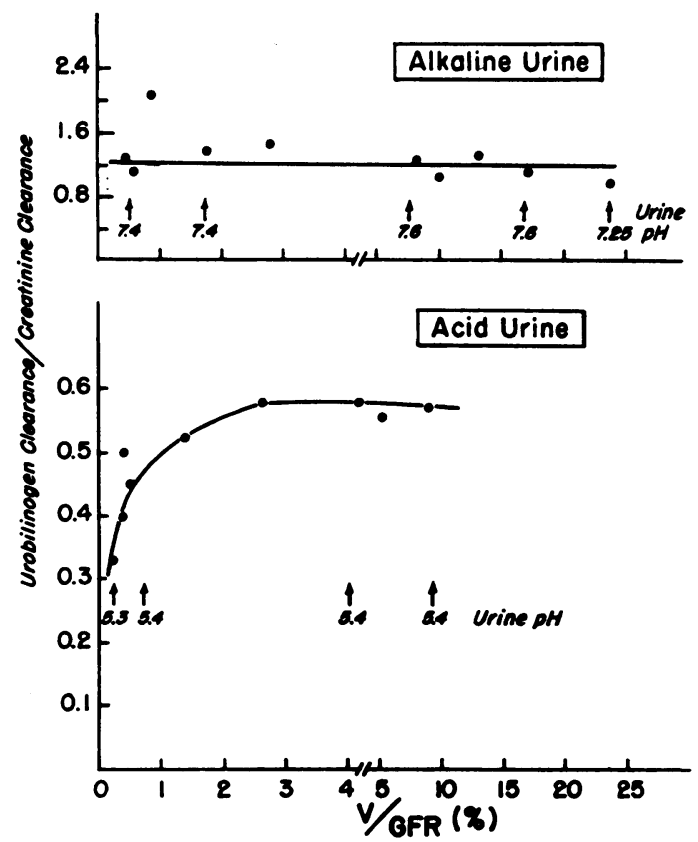

FIgURE 2 Effect of osmotic diuresis on urobilinogen ${ }^{8} \mathrm{H}$ excretion. Each point represents a single clearance period. The upper half of the figure shows an experiment testing response to $3 \%$ urea in saline when the urine was alkaline. The lower part of the figure shows the response to increasing urine flow during aciduria. The numbered arrows refer to urinary $\mathrm{pH}$ during each experiment. Lines through the points were drawn by inspection. 
TABLE III

Failure of Proximal Tubular Transport Inhibitors to Alter Urobilinogen Excretion

\begin{tabular}{ccc}
\hline \multirow{2}{*}{ Experiment } & \multicolumn{2}{c}{$\mathrm{C}_{\mathrm{u}} / \mathrm{C}_{\mathrm{er}}$} \\
\cline { 2 - 3 } & Control & Experimental \\
\hline
\end{tabular}

Probenecid (400-600 mg prime intravenously, then constant infusion of $12-18 \mathrm{mg} / \mathrm{min}$ )

1

2

3

4

5

6

0.89

0.74

0.90

0.85

0.81

0.86

0.79

0.78

0.93

1.00

0.93

0.74

Acetazolamide (500 $\mathrm{mg}$ intravenously)

$\begin{array}{lll}7 & 0.78 & 0.71 \\ 8 & 1.10 & 1.30 \\ 9 & 1.73 & 1.47\end{array}$

PAH (p-aminohippurate, $3 \mathrm{~g}$ prime intravenously, then constant infusion of 30 $\mathrm{mg} / \mathrm{min}$ )

10

1.07

1.04

$\mathrm{C}_{\mathrm{cr}}$, creatinine clearance. All other abbreviations as in Table I. Each value is the mean of 2-4 clearance periods. Periods were 6-10 min in length. Collections were begun 7-20 min after drug was started. All periods were collected during alkaline diuresis induced by $\mathrm{NaHCO}_{3}$ infusion; the infusion was adjusted to maintain urinary $\mathrm{pH}$ constant within $\pm 0.2 \mathrm{U}$ during the course of an experiment.

transport system of the proximal tubule. This was done in a total of six dogs during alkaline diuresis and with plasma levels of urobilinogen ${ }^{8} \mathrm{H}$ which varied from 50 to $1200 \mu \mathrm{g} / 100 \mathrm{ml}$. There was no demonstrable effect of probenecid in any experiment. Negative results were obtained in a few experiments under similar conditions with $p$-aminohippurate and acetazolamide, also known to inhibit the organic acid transport system. These experiments are summarized in Table III.

\section{DISCUSSION}

Previous studies have led to conflicting opinions as to the renal mechanisms for the excretion of urobilinogen. Using infusions of urobilin, Royer and Solari (2) concluded that urobilin and urobilinogen are excreted only by glomerular filtration in the dog, and by filtration and tubular secretion in man. Fassati, Fassati, and Andel (1) have recently claimed that glomerular filtration alone accounts for urinary urobilinogen in man.
Our data in the dog support the studies of Bourke et al. (3) in man concerning the mechanism of urobilinogen excretion. They concluded that urobilinogen is handled by the kidney in a fashion analogous to other weak organic acids, i.e., by a complex process of filtration, tubular secretion (probably in the proximal tubule), and reabsorption in the distal nephron by $\mathrm{pH}$-dependent nonionic back diffusion. Our studies show that when the urine is acid, urobilinogen excretion may be equivalent to as little as $30 \%$ of the filtered load. Under these conditions, increasing urine flow will increase urobilinogen excretion two- to threefold. Increasing urine $\mathrm{pH}$ to alkaline values will convert net reabsorption of urobilinogen into net secretion; in urines of maximal alkalinity, at least as much urobilinogen may be secreted as is filtered. Under these circumstances changes in urine flow do not affect urobilinogen excretion.

This pattern of $\mathrm{pH}$ and flow dependence is best explained by the laws governing nonionic diffusion (6). Urobilinogen is a weak acid (Fig. 3) whose $\mathrm{pK}_{\mathrm{a}}$ has been estimated by Bourke et al. (3) to be about 5.4. In acid urines, much of the urobilinogen will exist in the nonionic form. According to the principles of nonionic diffusion, the tubular epithelium is permeable to the nonionic form of organic acids. Hence, tubular reabsorption of urobilinogen will occur along the concentration gradient established by water reabsorption. When urine flow is increased by an osmotic diuretic, tubular reabsorption is limited because both the intratubular concentration of urobilinogen and the time available for back diffusion are decreased. In alkaline urines, most of the urobilinogen will exist in the ionic form. According to the principles of nonionic diffusion, tubular epithelium is considered to be impermeable to this molecular species. Hence, back diffusion of filtered and secreted urobilinogen will be minimal, and the urobilinogen clearance will be greater than that observed when the urine is acid. Since the concentration of the diffusible nonionic species is in any case minimal in alkaline urine, variations in urine flow can have little or no effect on back diffusion and clearance.

Nonionic diffusion by itself, however, cannot account for the net secretion of urobilinogen observed when the urine is alkaline. Many other 


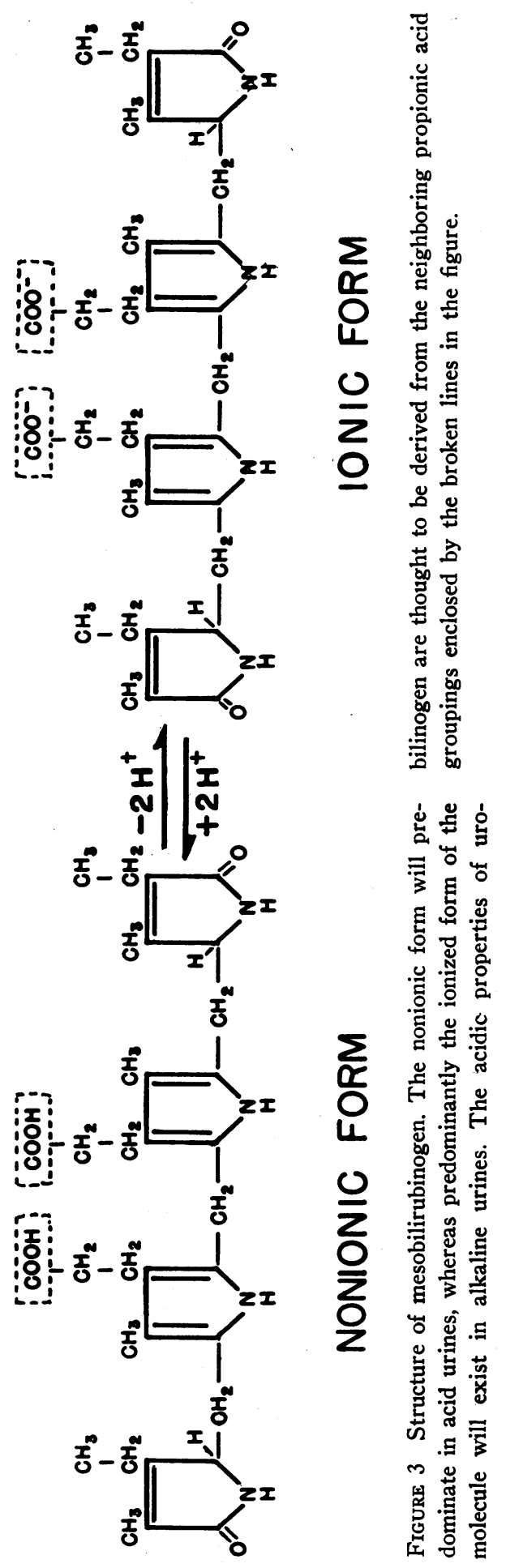


weak organic acids have been shown to be actively secreted, and studies suggest that a common secretory pathway may be present in the proximal tubule $(7,8)$. It would seem reasonable that this proximal organic anion secretory mechanism might be the site at which urobilinogen is secreted. Hence, it was rather surprising that probenecid, acetazoleamide, and $p$-aminohippurate, known inhibitors of this mechanism, had no influence on urobilinogen excretion in our studies. The dose of probenecid we used will depress salicylate excretion markedly (8). Bourke et al. (3) state that in man probenecid did inhibit urobilinogen secretion. However, these authors noted only a small response in one of three subjects studied, and their results seem inconclusive.

The failure of probenecid to alter urobilinogen excretion could be due to several causes. First, it could be that urobilinogen is tightly and preferentially bound to the transport carrier and cannot be dislodged by competitive inhibitors. Secondly, urobilinogen, an endogenous weak acid, might be handled by a separate transport system not inhibited by probenecid rather than by the probenecidsensitive mechanism for exogenous organic acids. This is a distinct possibility, since recent unpublished studies by one of us (R.L.) have shown that probenecid also fails to inhibit urobilinogen excretion by the rat liver. Since Despopoulos and Sonnenberg (9) have provided evidence that kidney and liver organic acid secretory pathways correspond both as to the compounds transported and in susceptibility to probenecid inhibition, it seems quite possible that urobilinogen is indeed secreted by a different mechanism from that which secretes substances such as salicylateș.

Finally, it is theoretically possible that weak acids might be secreted into the urine within the renal medulla by passive diffusion, if the concentration of nonionic urobilinogen in vasa recta plasma were increased by concentration and increased acidity of the plasma. However, net secretion in some of our studies was equal to filtered load, i.e., equivalent to the total urobilinogen in about $15 \%$ of renal plasma flow. ${ }^{2}$ Since total medullary plasma flow is probably less than this

\footnotetext{
2 In the anesthetized dog, glomerular filtration is about $30 \%$ of renal plasma flow, and approximately half of the plasma urobilinogen is not bound and hence filtrable.
}

(10), secretion in the medulla cannot account for the maximum rates of secretion in our experiments.

Given the instability of the urobilinogen molecule it is conceivable that errors in the measurement of protein binding could spuriously account for net secretion. However, it would require enormous errors in the measurement of protein binding to account for the observed ratios of $\mathrm{C}_{\mathrm{u}} / \mathrm{C}_{\mathrm{cr}}$ as high as 2 . This is most unlikely since two separate methods, ultracentrifugation and ultrafiltration, gave very similar results for human serum in our studies. Moreover, the values we obtained were very similar to those reported by Bourke et al. (3), who employed still a third method, equilibrium dialysis.

We have made the not unreasonable assumption in these experiments that the isotope used, mesobilirubinogen $-{ }^{3} \mathrm{H}$, is indeed a representative urobilinogen. Moreover, we measured only the exogenous urobilinogen with our techniques. In the tracer experiments, total urobilinogen concentration was roughly twice the probable physiological levels (3). Within these limitations, our results have an important clinical bearing. They demonstrate quite clearly that the urinary concentration of urobilinogen may reflect not only plasma levels, but also renal function, rates of urine flow, and urinary $\mathrm{pH}$. Varying amounts of urinary urobilinogen may be excreted in the face of constant plasma levels, if flow and $\mathrm{pH}$ are altered. In our studies, during steady states, the fraction of infused urobilinogen excreted in the urine increased from $2-3 \%$ in acid urines to $12-14 \%$ when the urine was made alkaline. Similar changes in the proportion of endogenous urobilinogen excreted in the urine may be anticipated. Therefore, clinical measurements of urinary urobilinogen can be interpreted as an index of plasma urobilinogen only if urinary $\mathrm{pH}$ and flow are considered.

\section{ACKNOWLEDGMENTS}

We wish to acknowledge the technical assistance of Miss Joanna Little and Mr. David Levinson, and the secretarial assistance of Mrs. Phyllis Tuttle.

These studies were supported in part by U. S. Public Health Service Grant Nos. AM09881, AM11793, and HE06795. Dr. Levy is supported by U. S. Public Health Service Traineeship No. AM05209. Dr. Lester is the recipient of U. S. Public Health Service Career Development Award 12,127. 


\section{REFERENCES}

1. Fassati, M., P. Fassati, and J. Andĕl. 1966. Vylučovánf urobilinogenu ledvinami (Renal excretion of urobilinogen). Casopis Lekaru. Ceskych. 105: 640.

2. Royer, M., and A. V. Solari. 1941. Depuración plasmática de la urobilina. Rev. Soc. Arg. Biol. 17: 329.

3. Bourke, E.; M. D. Milne, and G. S. Stokes. 1965. Mechanism of renal excretion of urobilinogen. Brit. Med. J. 2: 1510.

4. Lester, R., and P. D. Klein. 1966. Bile pigment excretion: a comparison of the biliary excretion of bilirubin and bilirubin derivatives. J. Clin. Invest. 45: 1839.

5. Klein, P. D., and R. Lester. 1966. The introduction of tritium into bile pigments. The Second Eur- atom Conference on Preparation and Storage of Labelled Molecules, Brussels. In press.

6. Milne, M. D., B. H. Scribner, and M. A. Crawford. 1958. Non-ionic diffusion and the excretion of weak acids and bases. Am. J. Med. 24: 709.

7. Weiner, I. M., and G. H. Mudge. 1964. Renal tubular mechanisms for excretion of organic acids and bases. Am. J. Med. 36: 743.

8. Weiner, I. M., J. A. Washington, and G. H. Mudge. 1959. Studies on the renal excretion of salicylate in the dog. Bull. Johns Hopkins Hosp. 105: 284.

9. Despopoulos, A., and H. Sonnenberg. 1967. Congruence of excretory functions of liver and kidney: sulfonamides. Am. J. Physiol. 212: 1117.

10. Thurau, K. 1964. Renal haemodynamics. Am. J. Med. 36: 698. 